\title{
Relationship between Social Networks and Customer Acquisition in the Field of IT Solutions
}

\author{
Franklin CORDOVA-BUIZA, Pierre Eduardo URTEAGA-ARIAS and \\ José Antonio CORAL-MORANTE
}

Universidad Privada del Norte

Correspondence should be addressed to: Franklin CORDOVA-BUIZA; franklin.cordova@upn.edu.pe

Received date:4 May 2021; Accepted date:23 November 2021; Published date: 27 January 2022

Copyright (C) 2022. Franklin CORDOVA-BUIZA, Pierre Eduardo URTEAGA-ARIAS and José Antonio CORAL-MORANTE. Distributed under Creative Commons Attribution 4.0 International CC-BY 4.0

\begin{abstract}
Social networks have allowed more direct communication with companies' target audience, segmenting the ads to streamline marketing efforts, help improve the brand's image, and increase the visibility of products to get closer to users with promotional tools. This research aims to demonstrate the relationship between social networks and customer acquisition in a Peruvian IT solutions company. The research method is quantitative, correlational, crosssectional, and non-experimental; regarding the data collection technique and instrument, the survey and the application of a questionnaire were used to a sample of the DyHosting company located in the city of Cajamarca, Peru. The results show a significant relationship between social networks and customer acquisition; likewise, the results recommend that organizations that start implementing digital marketing plans apply social networks as a business model to attract customers to their organizations.
\end{abstract}

Keywords: Social networks; customer acquisition; digital marketing.

\section{Introduction}

Lately, technology has been advancing and changing understanding of the world and dealing with it. Evolution has affected people's day-to-day lives and the routines of companies and entrepreneurs who are forced to adapt to new forms of work (Martín, 2018). Likewise, Miranda,
Magueta, Barbosalas, and Carvalho (2020) mention that the sales of products or services through digital media have seen a considerable increase in recent years, increasing the method consumers choose to purchase products or services.

If something is clear, it is that, at present, a web page is no longer enough to attract

Cite this Article as: Franklin CORDOVA-BUIZA, Pierre Eduardo URTEAGA-ARIAS and José Antonio CORAL-MORANTE (2022)," Relationship between Social Networks and Customer Acquisition in the Field of IT Solutions", IBIMA Business Review, Vol. 2022 (2022), Article ID 631332, DOI: $10.5171 / 2022.631332$ 
customers on the Internet. If a company needs to achieve this, it must consider using a digital marketing strategy. Unlike traditional advertising, where the company is the one who must interrupt and get the user's attention, with digital marketing, it is the potential customer who takes action and the initiative to contact the company. Most digital marketing strategies do not require a significant investment of money, but they require time and dedication (Barón, 2018). Currently, companies must adapt quickly to new business models to publicize their products and services, likewise, stay in the competitive market and excel in the field they perform. The general problem of the research is: What relationship exists between social networks and the acquisition of clients of the DyHosting company in the city of Cajamarca in the year 2020 ?

Forbes (2014) states that, today, 95\% of the world population with Internet access has a social network. Technology plays a vital role in companies; it is a resource used to develop and grow in the market. Companies face an increasingly competitive environment, generating instability by not adapting to technological changes, being an essential factor for the development of organizations. During the last 10 years, social networks have allowed maintaining a connection with active users in accounts called profiles, where the user puts certain information about his person, likes, spends time, hobbies and interests so that companies have direct contact to achieve the primary information of their target market segment about the product they offer (Mendoza, 2017).

Many are covered when social networks are studied, but for this research, trend social networks were considered: Facebook, WhatsApp, YouTube, and Instagram, which are currently the most used social networks in the world. In recent months, a report by Digital in 2020 shows the following results: Facebook is the leading social network with 2,449 million users worldwide, YouTube is the social network with audiovisual content and has 2 billion users, following this, WhatsApp leading among the social messaging networks with 1,600 million and finally Instagram with 1,000 million users (Hansen, 2021). These indicators show that most of the world's population uses social networks and they are practical tools that are found in people's daily lives.

Social networks are the perfect complement to achieve customer acquisition in companies, obtaining better results. The support of social networks is essential for disseminating information and knowledge to be very competent. As observed by $\mathrm{He} \&$ Wang (2016), companies have the challenge of integrating social networks since they are complex and informal. Rey (2012) points out that Latin America has proven to be the region with the fastest-growing audience on the Internet, considering that it is a market where most users are young people under 35 years old, together with Venezuela, Colombia and Mexico being the countries with the youngest users.

In 2013, a study on digital marketing and social networks carried out by the Mexican Internet Association (AMIPCI) highlighted that most Mexican citizens use social networks, and statistical data of the year 2014 of the Owloo company show that Mexico has 56 million users on Facebook, representing some potential clients for companies (Kaplan and Haenlein, 2010; Galvez, 2013). An unsurpassed social media marketing strategy can empower these relationships and improve performance. Today, social networks are an indispensable tool in any marketing strategy; their communication power is comparable to their power to capture, attract and retain customers (Morán, 2017).

More than 2 million people have a profile on Facebook, which strengthens friendships and promotes businesses or cultural spaces in Peru. Social networks are the key for companies to have the firmness to maintain their relationship with customers and to attract new ones. The objectives established by the company must be considered to implement a social media plan where customers are involved. For companies, creating an effective marketing campaign on social networks will allow them to save 
money on advertising, also generate a more unique and pleasant type of advertising being better received by consumers, establish a closer relationship with them, and generate loyalty from Mark. To obtain good results, organizations must interact daily on social networks, show interest through communication platforms, and cultivate relationships with customers (Lee et al., 2012; Chaffey et al., 2012).

On the other hand, Mesén (2011) states that "customer acquisition contemplates the attraction, development, maintenance and retention of customer relationships; the creation of loyal customers is the central axis of attracting customers and to getting them" (p.15).

Arellano (2010) states that customer acquisition, at present, "is much closer to the traditional philosophy of hard selling (sell now at any cost), and not to the marketing philosophy, which seeks a relationship of long term, that is, a continuous succession of sales" (p.19).

According to Nolasco (2016), it is essential to note that despite having a vision of market expansion, the company currently presents a lack of definition and implementation of an effective marketing strategy. This situation results in a lag in front of the competition in the market, slow growth (which seems to be only a response to consumer needs and not a marketing strategy), and low awareness of the company among market participants. Abuhashesh, Al-Khasawneh, Al-Dmour and Masa'deh (2019) mention that marketers should take advantage of viral marketing and word of mouth marketing, improving brand equity and increasing brand equity consumer interaction.

The research's objective is to determine the relationship between social networks and the acquisition of clients of the company DyHosting in the city of Cajamarca in 2020. The general hypothesis is that there is a positive and significant relationship between social networks and the acquisition of clients of the DyHosting company in the city of Cajamarca in 2020.
The research is justified by contributing to the knowledge of social networks in attracting customers. Social networks allow new forms of communication through multimedia content, generating interaction with the client, and this research helps to understand its better application so that entrepreneurs have practical tools in their decision-making.

\section{Materials And Methods}

The research is quantitative, correlational, cross-sectional, and non-experimental. Quantitative research is generated from a deductive process considering that cognition must be objective, in which, through numerical medication and inferential statistical analysis, the previously formulated hypotheses are tested (Hernández, 2014).

To conduct the research, the population consisted of 110 clients of the DyHosting company and a probabilistic sample of 89 clients. According to Bernal (2010), the sample is "part of the population which gives information, and it is measured and observed with the variables under study" (p.161).

The technique used is the survey, the instrument, formulated on a Likert scale, was validated with a Cronbach's Alpha 0.963 and the judgment of 5 experts. Subsequently, the information was collected with the questionnaire entered on the Google Forms platform. For the presentation of the results, the frequency table and horizontal bar graphs were used, the Pearson coefficient to determine the correlation between both variables, and finally, the Anova table to find the quadratic mean and determine the significance for acceptance of the study hypothesis. The statistical program used was IBM SPSS.

\section{Results And Discussion}

The procedure to collect and analyze the questionnaire data consisted of 6 parts: preparation, review, application, analysis, 
obtaining results and finally attaching to the report.

\section{Cronbach's Alpha}

Table 1: Reliability statistics

\begin{tabular}{|l|l|l|}
\hline Cronbach's Alpha & $\begin{array}{c}\text { Cronbach's Alpha based on } \\
\text { standardized elements }\end{array}$ & No. of elements \\
\hline, 962 &, 963 & 89 \\
\hline
\end{tabular}

Cronbach's alpha has a value of 0.962 ; it is very close to 1 , which means that the instrument is of internal consistency with a

Descriptive Research tendency to high reliability.

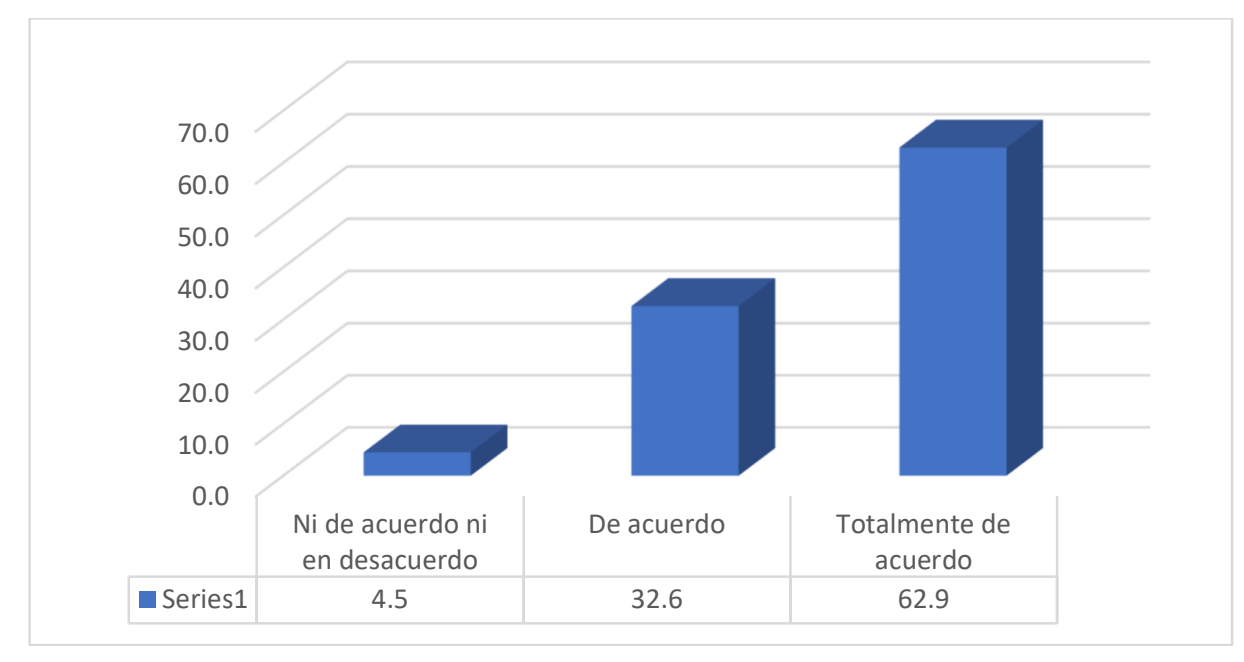

Fig 1. Importance of social networks today

In Figure 1, 63\% of those surveyed stated that they fully agree on the importance of social networks. 


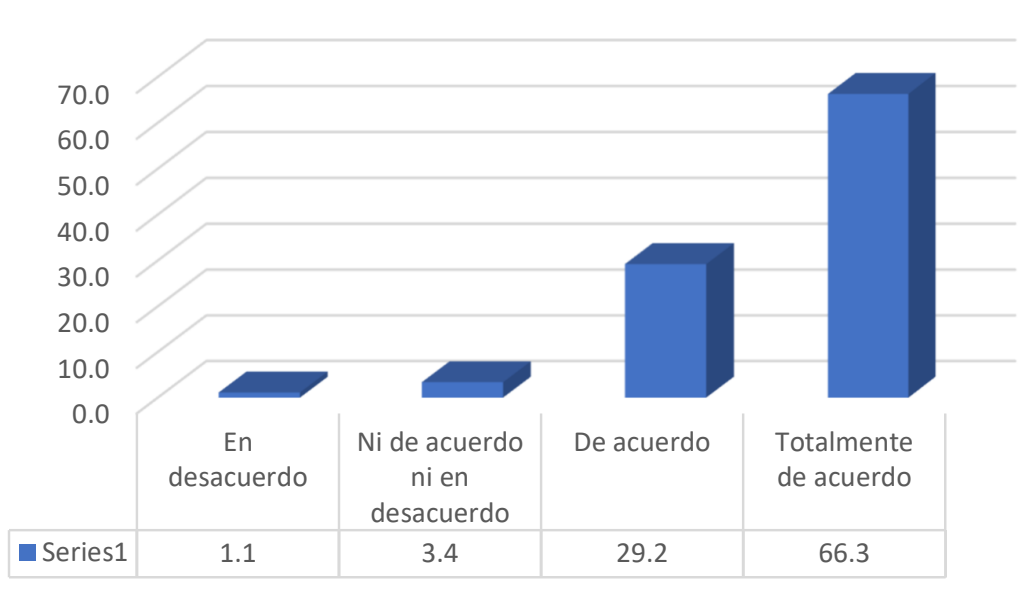

Fig 2. The DyHosting company must have a presence on social networks.

In figure $2,63 \%$ of those surveyed stated that they fully agree that the DyHosting company should have social networks.

Table 2: The DyHosting company must establish promotions and discounts through social networks

\begin{tabular}{|l|l|c|c|c|c|}
\hline \multicolumn{2}{|c|}{} & Frequency & Percentage & $\begin{array}{c}\text { Valid } \\
\text { Percentage }\end{array}$ & $\begin{array}{c}\text { Accumulated } \\
\text { percentage }\end{array}$ \\
\hline \multirow{3}{*}{ Valid } & Disagree & 2 & 2,2 & 2,2 & 2,2 \\
\cline { 2 - 6 } & $\begin{array}{l}\text { Neither agree nor } \\
\text { disagree }\end{array}$ & 7 & 7,9 & 7,9 & 10,1 \\
\cline { 2 - 6 } & Agree & 28 & 31,5 & 31,5 & 41,6 \\
\cline { 2 - 6 } & Strongly agree & 52 & 58,4 & 58,4 & 100,0 \\
\cline { 2 - 6 } & Total & 89 & 100,0 & 100,0 & \\
\hline
\end{tabular}

In table $3,58 \%$ of the respondents stated that they fully agree that the DyHosting company should establish promotions and discounts through social networks. 
Table 3: Companies must have different social networks to offer their products and services

\begin{tabular}{|l|l|c|c|c|c|}
\hline \multicolumn{2}{|l|}{} & Frequency & Percentage & $\begin{array}{c}\text { Valid } \\
\text { percentage }\end{array}$ & $\begin{array}{c}\text { Accumulated } \\
\text { percentage }\end{array}$ \\
\hline Valid & Disagree & 1 & 1,1 & 1,1 & 1,1 \\
\cline { 2 - 6 } & $\begin{array}{l}\text { Neither agree nor } \\
\text { disagree }\end{array}$ & 6 & 6,7 & 6,7 & 7,9 \\
\cline { 2 - 6 } & Agree & 37 & 41,6 & 41,6 & 49,4 \\
\cline { 2 - 6 } & Strongly agree & 45 & 50,6 & 50,6 & 100,0 \\
\cline { 2 - 6 } & Total & 89 & 100,0 & 100,0 & \\
\hline
\end{tabular}

In table 4 , it is observed that $50 \%$ of the respondents stated that they fully agree that the DyHosting company has different social

Correlation al Research networks to offer its products and services.

Table 4: General Hypothesis correlation

\begin{tabular}{|c|c|c|c|}
\hline & & VI & VD \\
\hline \multirow[t]{3}{*}{ VI } & Pearson's correlation & 1 &, $846^{* *}$ \\
\hline & Sig. (bilateral) & & ,000 \\
\hline & $\mathrm{N}$ & 89 & 89 \\
\hline \multirow[t]{3}{*}{ VD } & Pearson's correlation & ,846** & 1 \\
\hline & Sig. (bilateral) &, 000 & \\
\hline & $\mathrm{N}$ & 89 & 89 \\
\hline
\end{tabular}

There is a positive correlation of $84.6 \%$ and a significance level of 0.000 being less than 0.05 ; therefore, the null hypothesis (Ho) is rejected because social networks influence the acquisition of clients of the DyHosting company in the city of Cajamarca, 2020.

Table 5: Specific Hypothesis correlation 1

\begin{tabular}{|c|c|c|c|}
\hline & & VI & VD \\
\hline \multirow{3}{*}{$\begin{array}{l}\text { The DyHosting company } \\
\text { must have its web pages. }\end{array}$} & Pearson's correlation & 1 &, $457^{* *}$ \\
\hline & Sig. (bilateral) & &, 000 \\
\hline & $\mathrm{N}$ & 89 & 89 \\
\hline \multirow{3}{*}{$\begin{array}{l}\text { The employees of the } \\
\text { DyHosting company must } \\
\text { have a good } \\
\text { predisposition to clear up } \\
\text { all the doubts of the } \\
\text { clients. }\end{array}$} & Pearson's correlation &, $457^{* *}$ & 1 \\
\hline & Sig. (bilateral) & 000 & \\
\hline & $\mathrm{N}$ & 89 & 89 \\
\hline
\end{tabular}

There is a positive correlation of $45.7 \%$ between social networks and customer acquisition.

Franklin CORDOVA-BUIZA, Pierre Eduardo URTEAGA-ARIAS and José Antonio CORAL-

MORANTE, IBIMA Business Review, DOI: 10.5171/2022.631332 
Table 6: Specific Hypothesis correlation 2

\begin{tabular}{|c|c|c|c|}
\hline & & V1 & V2. \\
\hline \multirow{3}{*}{$\begin{array}{l}\text { The DyHosting company } \\
\text { must have a presence on } \\
\text { social networks. }\end{array}$} & Pearson's correlation & 1 & $632^{* *}$ \\
\hline & Sig. (bilateral) & & 000 \\
\hline & $\mathrm{N}$ & 89 & 89 \\
\hline \multirow{3}{*}{$\begin{array}{l}\text { The time you wait to be } \\
\text { seen is acceptable. }\end{array}$} & Pearson's correlation & ,632 & 1 \\
\hline & Sig. (bilateral) & ,000 & \\
\hline & $\mathrm{N}$ & 89 & 89 \\
\hline
\end{tabular}

There is a positive correlation of $63.2 \%$ between social networks and customer acquisition in the company DyHosting in Cajamarca in 2020.

Table 7: Anova

\begin{tabular}{|l|l|c|c|c|c|c|}
\hline \multicolumn{2}{|c|}{} & $\begin{array}{c}\text { Sum of } \\
\text { squares }\end{array}$ & gl & $\begin{array}{c}\text { Mean } \\
\text { square }\end{array}$ & F & Sig \\
\hline \multicolumn{2}{|c|}{ Inter subjects } & 626,264 & 88 & 7,117 & & \\
\hline \multirow{2}{*}{$\begin{array}{l}\text { Intra } \\
\text { subjects }\end{array}$} & $\begin{array}{l}\text { Between } \\
\text { elements }\end{array}$ & 61,864 & 29 & 2,133 & 7,962 &, 000 \\
\cline { 2 - 8 } & Residue & 683,736 & 2552 &, 268 & & \\
\cline { 2 - 8 } & Total & 745,600 & 2581 &, 289 & & \\
\hline \multicolumn{2}{|c|}{ Total } & 1371,864 & 2669 &, 514 & & \\
\hline
\end{tabular}

According to the results extracted in table 8 of ANOVA, it is indicated that the significance found is 0.000 , which is less than 0.05; therefore, the null hypothesis (Ho) is rejected for this reason social networks influence the recruitment of clients of the DyHosting company, in the city of Cajamarca, 2020.

\section{Discussion}

The research shows that social networks are essential means to establish a clientcompany relationship, so IT solutions companies need to have a presence on social networks. It is observed that the clients of the DyHosting company considering that social networks are vital today; therefore, the company must have a presence in them to offer its products and services more effectively, involving customers and making them part of the promotions or discounts that the company may offer.

The company does not yet have a significant and continuous presence on social media. On the other hand, it was observed that the clients of the DyHosting company prefer social networks as a means of contact with the company because the company will be able to provide information in a more accessible, more straightforward, and good quality way. In addition, it will offer promotions and discounts to build loyalty or attract potential customers, offering better products and services than the competition. 
According to the results obtained in the general hypothesis, it was possible to determine that social networks influence customer acquisition in an essential way in the DyHosting company, this considering that there is a significance found of 0.000 , which is less than 0.05 , for which the null hypothesis (Ho) is rejected, for this reason, the research hypothesis is accepted. Therefore, there is a significant relationship between social networks and the acquisition of clients of the DyHosting company in Cajamarca.

Social networks are part of digital marketing since they allow a dialogue between the distribution channel members in a direct, massive, and straightforward way (Vela, 2014; Akdogan and Altuntas, 2015). As Caleya (2008) explains, most companies will wonder if it is convenient to have social media profiles. Companies that use this type of instrument can contribute to the positioning of their brand and increase their sales. If they are not used correctly and permanent monitoring is not carried out, the effect would be harmful since the expectation of the users would be disappointed by leaving aside an efficient interaction tool. Web 2.0 spaces have been configured as an instrument for advertisers' business strategies in the digital landscape. The listening skills of current and potential customers and creating communities around the brand facilitate the companies accelerate a business orientation directed to the client (Morán, 2017).

On the other hand, the results coincide with the studies carried out by Uribe et al. (2013) about the use of digital social networks as a marketing tool in business performance. The results showed that this intensity moderates the relationship between market orientation with performance and with entrepreneurial orientation. A solid and determined social media marketing strategy can enhance these relationships and improve performance.

Social networks allow direct communication with customers without investing heavily in money (Belo et al., 2013). Consequently, marketing costs will decrease (Kozinets, 2002; Ellison, 2007). There is also a reduction in the costs of technical services (Dholakia and Vianello, 2006); they even help to create emotional ties, and strengthen levels of brand loyalty (Koh and Kim, 2004).

Also, the results coincide with Rojas (2014), who mentions that social networks have changed traditional advertising, moving to a modern and innovative space, improving commercial activity, since they allow collaborative marketing, obtaining a competitive advantage, inquiring about the needs of your consumers, more easily knowing the profile of your consumer, and generating an interaction for the development of the brand.

Social networks are instruments of interaction, simple means of communication, but with a much greater reach and impact than other traditional means, with a presence of dynamism and interaction superior to any other means of communication. Social networks allow establishing a faster and more efficient contact; this result coincides with Escobar (2013), who mentions the same for the acquisition of clients of the Cooperativa de Ahorro y Crédito Universidad Técnica de Ambato Ltda. Finally, social networks today are indispensable tools in any marketing strategy. Their communication power is comparable to their power to attract and capture new clients for companies (Morán, 2017).

We are currently going through a global pandemic crisis due to a virus called Covid19 that expands daily. In turn, human losses are increasing, causing the government to put specific regulations that must be met to safeguard our lives; one of them is the obligatory social isolation being a limitation for the development of the investigation. This rule is difficult to collect data in person, also does not allow interaction with the representative and customers of the company; physical contact is essential to generate a special bond on the part of the researcher; despite this difficulty, the research has been successfully developed to respond to the study variables. 


\section{Conclusion}

The research shows that social networks and customer acquisition positively correlated with DyHosting in Cajamarca in 2020. Contrasting the results obtained from the Pearson correlation test, the study variables have a relationship level of $84.6 \%$ and a significance lower than 0.05. Likewise, the results obtained from the surveys indicated that social networks are currently essential means of communication and companies should have a presence in them. Finally, organizations are advised to start implementing digital marketing plans, including social media strategies, applying social networks as a new business model to attract customers to their organizations.

\section{References}

- Akdogan, M., \& Altuntas, B. (2015). Covert Marketing Strategy and Techniques. Procedia-Social and Behavioral Sciences, 207, 135-148, DOI: 10.1016/j.sbspro.2015.10.162.

- Arellano R. (2010). Comportamiento del consumidor: Enfoque América Latina (2nd. Ed.) [Consumer behaviour: Focus on Latin America] México: Mc Graw-Hill.

- $\quad$ Barón, S., Fermín S. \& Molina E. (2018). Estrategias de mercadeo basadas en el marketing digital orientadas a la captación de nuevos clientes de las pymes [Marketing strategies based on digital marketing aimed at attracting new clients from SMEs]. Caso de estudio: Grupo Inter Game 2012, C.A. Enfoques, 164 -174.

- Belo, A., Castela, G., \& Fernandes, S. (2013). Ambientes Colaborativos Virtuais: potencial das redes sociais. $\mathrm{O}$ caso das empresas do Algarve [Virtual Collaborative Environments: the potential of social networks. The case of companies in the Algarve]. RISTIRevista Ibérica de Sistemas $e$ Tecnologias de Informação, 12, 65-79, DOI: 10.4304/risti.12.65-79.

- Bernal, C. (2010). Metodología a la Investigación Científica, (3ra. Ed.). México D.F.: Mc Graw-Hill.
- Celaya, J. (2008). La Empresa en la WEB 2.0. España: Grupo Planeta.

- Cláudia Miranda Veloso, Daniel Magueta, Bruno Barbosa Sousa \& José Luís Carvalho (2020). Medición de la Calidad, Satisfacción y Fidelización del Servicio Electrónico en el Canal Online del Modern Retail [Measurement of Quality, Satisfaction and Loyalty of the Electronic Service in the Online Channel of Modern Retail]. IBIMA Business Review, (2020), ID de artículo 531781, DOI: 10.5171 / 2020.531781

- Chaffey, D., Smith, P., \& Smith, P. (2012). eMarketing eXcellence: Planning and optimizing your digital marketing. Routledge.

- Dholakia, U., \& Vianello, S. (2006). A study of sharing in consumer communities. In 35th EMAC Conference, Atenas, 23-26.

- Ellison, N. (2007). Social network sites: Definition, history, and scholarship. Journal of ComputerMediated Communication,' 13(1), 210230, DOI: $\quad 10.1111 / \mathrm{j} .1083-$ 6101.2007.00393.

- Escobar, S. (2013). El Marketing Digital y la Captación de Clientes de la Cooperativa de Ahorro y Crédito [Digital Marketing and Customer Acquisition of the Cooperativa de Ahorro y Crédito]. Universidad Técnica de Ambato Ltda (Bachelor's thesis).

- $\quad$ Forbes. (2014), December 23). Forbes México. Retrieved from: https://www.forbes.com.mx/redessociales-en-la-empresa/

- Gálvez I. (2013). Facebook para

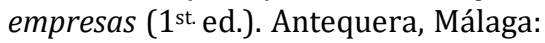
Editorial IC.

- Hansen, E. B., \& Bøgh, S. (2021). Artificial intelligence and internet of things in small and medium-sized enterprises: A survey. Journal of Manufacturing Systems, 58, 362-372. DOI:

https://doi.org/10.1016/j.jmsy.2020. 08.009

- He, W., \& Wang, F. K. (2016). A process-based framework of using social media to support innovation 
process. Information Technology and Management, 17(3), 263-277.

- Hernández, R., Fernández, C. \& Baptista, P. (2014). Metodología de la investigación ( $6^{\underline{a}}$ ed.), México: McGrwall Hill Education.

- Hernández, R., Fernández, C., \& Baptista, P. (2010). Metodología de la investigación. MC Graw-Hill, 149.

- Kaplan, A., \& Haenlein, M. (2010). Users of the world, unite! The challenges and opportunities of social media. Business Horizons, 53, 59-68. DOI: 10.1016/j.bushor.2009.09.003.

- $\quad$ Kerlinger, Fred \& Lee, Howard. (2002). Investigación del Comportamiento, Métodos de Investigación en Ciencias Sociales. McGraw Hill. México.

- Koh J., y Kim, D. (2004). Knowledge sharing in virtual communities: an ebusiness perspective. Expert systems with applications, 26(2), 155-166. DOI: 10.1016/S0957-4174(03)00116-7.

- Kotler, P. \& Armstrong, G. (2008). Fundamentos del marketing. (8th. ed.), México D.F.: Editorial Pearson.

- Kozinets, R. (2002). The field behind the screen: using netnography for marketing research in online communities. Journal of marketing research, 39(1), 61-72, DOI: http://dx.doi.org/10.1509/jmkr.39.1. 61.18935

- $\quad$ Lee, W., Xiong, L., \& Hu, C. (2012). The effect of Facebook users arousal and valence on intention to go to the festival: Applying an extension of the technology acceptance model. International Journal of Hospitality Management, 31 (3), 819-827, DOI: 10.1016/j.ijhm.2011.09.018.

- Martín, L. (2018, September 27) La Verdad. Retrieved from: https://www.laverdad.es/nuestraeconomia/adaptacion-nuevastecnologias- 20180927010343ntvo.html

- $\quad$ Mendoza, L. (2017). Publicidad digital y redes sociales dirigidas a jóvenes de la ciudad de Sucre [Digital advertising and social networks aimed at young people in the city of Sucre]. Revista Investigación y Negocios, 10(15), 186198.
- Mesén, J. (2011). Mercadotecnia. (4ta. Ed.), México: Limusa.

- Mohammd Abuhashesh, Mohammad Al-Khasawneh, Rand Al-Dmour \& Ra'ed Masa'deh (2019). El impacto de Facebook en el proceso de decisión de los consumidores jordanos en la selección de hoteles [The impact of Facebook on the decision process of Jordanian consumers in the selection of hotels]. IBIMABusiness Review, (2019), ID de artículo 928418, DOI: 10.5171 / 2019.928418

- Morán, J. \& Cañarte, T. (2017). Redes sociales factor predominante en la fidelización del cliente [Social networks predominant factor in customer loyalty]. Dom. Cien., ISSN: 2477-8818, 519-532.

- Nolasco, K., Almazán, D. \& Quintero, J. (2016). Análisis de la percepción de uso de las redes sociales como herramienta de marketing en las MiPYMES de Tamaulipas, México [Analysis of the perception of social networks as a marketing tool in the MiPYMES of Tamaulipas, Mexico]. RISTI - Revista Ibérica de Sistemas e Tecnologias de Informação, (18), 4965.

- $\quad$ Rey, N. (2012). Marketing Digital, (8va Ed), España: Editorial Conde Nast

- Rojas Valerio, I. (2014). La publicidad en las redes sociales: impulso a las microempresas en crecimiento [Advertising on social networks: a boost to growing micro-businesses]. [consulta 25 agosto 2017]. Available in:

www.ulacit.ac.cr/files/careers/100_r ojasilapublicidadenlasredessociales.p df

- Sánchez, H., \& Reyes, C. (2015). Metodología y diseños en la investigación científica (4ta. Ed) Lima: Editorial Visión Universitaria, 59.

- Uribe Saavedra, F., Rialp Criado, J., \& Llonch Andreu, J. (2013). The use of social networks as a marketing tool in the business performance. Cuadernos de administración, 26(47), 205-231.

- Vela, D. (2014). Social Media Manager. Edición española, Ediciones Anaya Multimedia, Grupo Anaya, S.A. 